\title{
THE INFLUENCE OF GRAMMAR AND VOCABULARY MASTERY ON STUDENTS' READING COMPREHENSION AT LANGUAGE DEVELOPMENT CENTER OF UIN SUSKA RIAU
}

\author{
Muharni \\ English lecturer of language Development Center UIN Suska Riau \\ email: muharni.hk@gmail.com
}

\begin{abstract}
The aims of the research were to find out the influences among the variables; (1) to find out the influence of grammar mastery on the students' reading comprehension, (2) to find out the influence of vocabulary mastery on the students' reading comprehension, and (3)to find out the influence of grammar (X1) and vocabulary mastery on the students' reading comprehension. The design of this research was a corelational research. The population was 150 the second level students of Language Development Center of UIN SUSKA Riau and 90 students were taken clusterly as samples. In collecting data, multiple choice tests were used as intruments. In the result of analysing data, Pearson Product Moment Correlation (SPSS 20) was used. The first finding of the research indicated that there was a positive influence between $\mathrm{X} 1$ and $\mathrm{Y}$ variables which was proved by two ways in interpreting the result of correlation where the value $r_{x y}=0.811$ was between $0.800-1.00$ meant very high influence and by comparing the value of $r_{x y}$ $=0.811$ with $t_{\text {table }}$ was $0.205<0.811>0.267$ that meant the $r_{x y}$ was a higher influence than $t_{\text {table. }}$ The second finding, there was a positive influence between $\mathrm{X} 2$ and $\mathrm{Y}$ variables which was showed by two ways in interpreting the result of correlation where the value $r_{x y}=0.735$ was between $0.600-0.800$, that meant high influence and by comparing the value of $r_{x y}$ with $t_{\text {table }}$ was $0.205<0.735>0.267$ that meant $r_{x y}$ was higher than $t_{\text {table. }}$ The last finding, there was a positive influence between $X 1$, $\mathrm{X} 2$ and $\mathrm{Y}$ variables altogether which was proved by two ways in interpreting the result of correlation where the value $R_{y \cdot x_{1} x_{2}}=0.82969$ was between $0.800-$ 1.00 , that meant very high influence and by comparing the value of $R_{y \cdot x_{1} x_{2}}=$ 0.82969 with table was " $0.205<0.82969>0.267$ " that meant $R_{y \cdot x_{1} x_{2}}$ was higher than $\mathrm{t}_{\text {table. }}$
\end{abstract}

Key words: Grammar mastery, Vocabulary mastery, Reading Comprehension
PENGARUH ANTARA PENGUASAAN TATABAHASA DAN KOSAKATA
TERHADAP PEMAHAMAN MEMBACA MAHASISWA DI PUSAT PENGEMBANGAN BAHASA UIN SUSKA RIAU

\begin{abstract}
Abstrak
Tujuan penelitian ini bertujuan untuk mengetahui pengaruh antara variable diantaranya; (1) mengetahui pengaruh penguasaan tatabahasa terhadap pemahaman membaca, (2) mengetahui pengaruh penguasaan kosakata bahasa
\end{abstract}


terhadap pemahaman membaca, (3) mengetahui pengaruh penguasaan tatabahasa dan kosakat terhadap pemahaman membaca. Rancangan Penelitian kajian ini adalah korelasi. Populasinya adalah 150 ahasiswa dari tingkat dua dan sample yang diambil adalah 90 mahasiswa yang dilakukan secara kelompokan kelas. Pilihan ganda dipilih sebagai alat pengumpulan data. Pearson Product Moment Correlation (SPSS 20) digunakan untuk menganalisis hasil data kajian ini. Dari hasil temuan pertama diketahui bahwa terdapat hubungan yang positif antara variabel $\mathrm{X} 1$ dan $\mathrm{Y}$ yang dibuktikan dengan dua cara penaksiran dari hasil hubungan tersebut dimana nilai $r_{x y}=0.811$ berada diantara $0.800-1.00$ yang berarti sangat tinggi pengaruhnya dan selanjutnya dengan membandingkan nilai dari $r_{x y}=0.811$ dengan $t_{\text {table }}$ yaitu $0.205<0.811>0.267$ yang berarti $r_{x y}$ memiliki pengaruh yang lebih tinggi dari $t_{\text {table. }}$ Hasil penemuan kedua terdapat pengaruh yang positif antara variabel $\mathrm{X} 2$ dan $\mathrm{Y}$ yang dibuktikan dengan dua cara penaksiran dimana nilai $r_{x y}=0.735$ berada diantara $0.600-0.800$ yang berarti tinggi pengaruhnya dan selanjutnya dengan membandingkan nilai dari $r_{x y}=0.735$ dengan $t_{\text {table }}$ yaitu $0.205<0.735>0.267$ yang berarti $r_{x y}$ memiliki pengaruh yang lebih tinggi dari $t_{\text {table. }}$ Hasil penemuan terakhir terdapat pengaruh yang positif bersamaan antara variabel $\mathrm{X} 1$ dan $\mathrm{X} 2$ dan $\mathrm{Y}$ yang dibuktikan dengan dua cara penaksiran dimana nilai $R_{y . x_{1} x_{2}}=0.82969$ berada diantara $0.800-1.00$ yang berarti sangat tinggi pengaruhnya dan selanjutnya dengan membandingkan nilai dari $R_{y \cdot x_{1} x_{2}}=0.82969$ dengan $\mathrm{t}_{\text {table }}$ yaitu $0.205<0.82969>0.267$ yang berarti $R_{y . x_{1} x_{2}}$ memiliki pengaruh yang lebih tinggi dari table.

Kata Kunci: Penguasaan Tatabahasa, Penguasaan Kosakata, Pemahaman Membaca

\section{INTRODUCTION}

In learning English, there are four language skills that should be mastered. They are listening, speaking, reading, and writing. The four skills mentioned are divided into receptive and productive skills. Speaking and writing are states productive skills, while listening and reading are receptive skills. Beside the four language skills above, reading is a great importance to students whose mother tongue is not English, because they almost do not

J-SHMIC, Vol 4, No 1, February 2017 have opportunity to hear or to speak that language.

Linse (2005:69) states reading is essential which is a set of skills that involves making sense and deriving meaning from the printed word. In order to read, the readers must be able to decode (sound out) the printed words and also comprehend what the readers read. It is important for the students to master reading because the goal of reading is to understand the texts and to be able to learn from the text. Reading is not only a process to identify text structure, vocabulary, and grammar, but also understand the meaning of the text contextually. It

The Influence of Grammar and Vocabulary Mastery on Students' Reading Comprehension at Language Development Center of UIN Suska Riau 
means that vocabulary and grammar contribute for the readers to comprehend the reading text.

In fact, more learners get problems in learning English. In Indonesia, for example, Wahyuni (2011) states that senior high school graduates who have learned English for six years, with almost 900 hours of school teaching, are unable to comprehend English reading text. This phenomenon can also be observed among university graduates and even among faculty members. The teaching of English has so far not helped teachers and students achieve their declared goals despite many efforts made to improve its quality.

In Language development Center of UIN SUSKA Riau, the second semester students who are not in English major should learn English too. They must master four language skills in English including reading comprehension. Teaching reading at Language Development Center of UIN SUSKA Riau is conducted based on the reading objectives in English curriculum. It is stated that in reading competence, the students are expected to understand the meaning of interpersonal and transactional written texts (LDC Syllabus of UIN Suska Riau: 2015). In other words, students are not only expected to understand the texts but also to link them in daily life contexts and to access knowledge.

To get some information about learning process in the classroom especially in reading comprehension, some of English lecturers in Language Development Center of UIN SUSKA Riau had been intrerviewed on February 15th 2015, and they said most of the students still had low ability in reading comprehension. They found that students had difficulties in comprehending reading text. The students got difficulties in comprehending the text in various aspects. They found in their research such as students' lack of vocabulary and grammar, lack of interest in the reading text, and lecturers' difficulties in guiding and managing their class to get appropriate reading strategy.

In addition, based on the preliminary study and temporary observation on March 23rd 2015 at the second level students of Animal Husbandry major at Language Development Center of UIN SUSKA Riau in the academic year 2015-2016, some of the students had also difficulties to comprehend the text because of the difficult words and found misunderstanding in intrepretating the text. In other words, they did not get the ideas of the text which they had read. On the other side, there were students who comprehended by guessing and their feeling from a few words which they read. Consequently, they got misunderstanding to comprehend the text such as identfying main idea, the detail information, reference, inference, and understanding vocabularies.

Based the description above, these problems commonly happen in every student, because their reading comprehension is still low. The way the learners use their reading skills significantly determine how they can achieve the objectives. It implies that if the learners have good reading skills, they be able to comprehend reading text well. There are factors that are probably play important role

The Influence of Grammar and Vocabulary Mastery on Students' Reading Comprehension at Language Development Center of UIN Suska Riau 
to improve the students' reading skill are grammar and vocabulary mastery. Beside such basic skill, the student has to master some vocabulary and know the grammar as well as possible to determine the type of the text.

Therefore, it is important to find out and to do the investigation whether there are really any influence between grammar and vocabulary mastery on the students ${ }^{6}$ reading comprehension. If there are found the influences among the variables, it should be suggested to attempt to build the reading comprehension among the students. It is the responsibility of all parts of people who really care of the development of the Nation.

\section{a. Definition of reading comprehension}

King and Stanley (2008:8) explain that there are five aspects in processing of reading comprehension. They are; finding factual information, finding main idea, finding the meaning of vocabulary in context, identifying reference, and making reference. The theory above can be described as follow:

a) Finding main idea

Reading concerns with meaning to a greater extend that it is with form. An efficient reader understands not only the ideas but also their relative significance as expressed by author, in order words, some of ideas are super ordinate while other subordinate. Thus, main idea is the most important piece of information the author wants the readers to know about the concept of the paragraphs.
Determining idea is a skill to grasp and find the main point of the passage by summarizing the passage and look for repetition of ideas or words.

b) Finding factual information/ details

Factual information requires readers to scan specific details. There are many types of question of factual information such as; question type of reason, purpose, result, comparison, means, identify, time, and amount which most of the answers can be found in the text. So, finding factual information/ details is the specific information or part of the text which means looking for the information that relevant to the goal in mind and ignores the irrelevant

c) Finding the meaning of vocabulary in context

It means that the readers could develop they guessing ability to the word which is unfamiliar with them, by relating the close meaning or unfamiliar words to the text and the topic of the text that is read. The words have the same meaning as another word. So, finding the meaning of vocabulary in context is understanding vocabulary what the words mean such as knowing their "form" (how they sounds, how they spell, grammatical change that could be made to them), their "meaning" (their conceptual content, and how they relate to other words and in particular types of language use.

d) Making references

Recognizing references words or phrases to which they refer will

The Influence of Grammar and Vocabulary Mastery on Students' Reading Comprehension at Language Development Center of UIN Suska Riau 
help readers understand the reading passage. Students of English might learn many rules for the sentences. Reference words are ussualy short and are frequently pronouns, such it, she, he, this, those, and so on. So, making reference is the intentional use of one thing to indicate something else in which one provides the information necessary to interpret the other. Moreover, finding reference means interpreting and determining one linguistic expression to another.

e) Identifying inference

The importance of reading is to understand what the writer wrote; it is expected that reader can infer the writer wrote. In order words, a good reader is able to draw inference logically and make accurate prediction. Therefore, Inference is a good guess or conclusion drawn based on logic of passage. Finding inference means the reader imply the sentence or passage understand and conclude it logically.

\section{b. The Concept of Grammar Mastery}

Nunan (2003: 32) described grammar as the ways in which units of language (principally, but not exclusively, words) combine together to form sentences. If the students understand the text, the researcher only knew that grammar is a mean to combine words into sentences.

From the above statement, the writer assumes that grammar is an important factor to be learnt. Grammar can not be separated from language, because if students do not have a good mastery in grammar they cannot master the language too. Grammar is partly study which forms or structures are possible in a language. It means that grammar is the factor that students need if they want to make a sentence in a good structure. Therefore, the students should have a good grammar mastery. By mastering grammar the students can understand easily how to make sentence and composition in a good order. So they are able to easily comprehend the text.

Therefore, the second level students of Language Development Center of UIN SUSKA Riau should be more comprehensive and more emphasis on the ability to construct English sentences with appropriate grammatical. Students should be able to master grammar such as past tense, present tense, present continuous, and etc. Besides that, students should be able to test in passive sentences, adverb connectors, and adjective caluses because those are steps learning English in the second level.

\section{c. The Concept of Vocabulary Mastery}

Thornbury (2002: 13) states that vocabulary is the important factor in reading. He also says that the larger vocabulary the easier it is to make the sense of text. Without vocabulary, it is difficult for students to obtain any kind of news and information that stated in any printed material. By having number of vocabulary, this kind of difficulty can be solved.

Fries (1990) has classified vocabulary into function and content words. The function words are a

The Influence of Grammar and Vocabulary Mastery on Students' Reading Comprehension at Language Development Center of UIN Suska Riau 
closed class, it means that the words cannot be added to the prepositions or auxiliaries or modals or any structure words of the language. On the other hand, the content words can be added to any times as new scientific advances make new words and communication about new inventions necessary.

The content words can be divided into three general classes as below:

a. Words naming things, ideas, entitles, that can be called as nouns

b. Words naming actions called verbs

c. Words used to describe the qualities of those things or action called adjective and adverbs.

It can be concluded that to be able to understand any kind of text in a foreign language, especially English, the learners are not only suggested to have the ability in grammar but they also need to master the vocabulary which is related to the type of text being read and learned. Without grammar, the sequence of words, thought and idea cannot be delivered accurately; and without vocabulary, there is nothing to be delivered.

In this correlational study, the writer did not focus on vocabulary mastery in general but only focus on the vocabulary which is related with syllabus at Language Development Center UIN SUSKA Riau for the second level. In the syllabus of LDC (2005), the vocabulary or words that are commonly used are content word such as nouns, verbs, adjective, and adverb which is the amount of words that students encountered based on what they have learned in the class.

\section{d.The Influence of Grammar and Vocabulary Mastery on the Students' Reading Comprehension}

Murcia (2001:149) states grammar and vocabulary have been viewed as competing elements in language teaching. It means that grammar and vocabulary have a great influence to the students' language skills, in this case reading comprehension. Mastering reading comprehension, people must learn about grammar and vocabulary, how they put into a sentence and use it to express their thought and feeling. So, students who want to get a text message have to know about how the text is form or they will not able to have a complete understanding about what the writer means.

According to Graham (2007:56) there are four skills needed when people learn English, they are listening, speaking, reading and writing. Besides, if someone learns English; she has to master the language components, such as: phonology grammar, vocabulary, and pronunciation to support the four skills because the four skills are very important. It meanst that to increase the skill in reading comprehension, students should master the language components such as; grammar, and vocabulary.

In addition, Krashen (2004:

72) explains that motivation to read and increased reading fluency along with knowledge of grammar and get in vocabulary. Thus, If students have good grammar and vocabulary 
mastery, they can read and comprehend the text correctly.

Linse (2005:69) states reading is essential which is a set of skills that involves making sense and deriving meaning from the printed word. In order to read, we must be able to decode (sound out) the printed words and also comprehend what we read . It is important for the students to master reading because the goal of reading is to understand the texts and to be able to learn from the text. Reading is not only a process to identify text structure, vocabulary, and grammar, but also understand the meaning of the text contextually. It means that vocabulary and grammar include to give contribution in comprehending reading text.

From explanation, vocabulary, grammar and reading have a close relationship.In reading, students need vocabulary and grammar to help them in understanding the idea, and in learning vocabulary, students need a lot of practice of reading because reading is the active way in learning vocabulary. So, if the students know a lot about vocabulary and grammar, they can easily comprehend the reading.

\section{METHOD}

The research design was a corelational research, because this research used ex post facto design because it did not give any treatment. This study collected the data and shown the influence of cause and effect that happened.The population is the second level students of Language Development Center of UIN SUSKA Riau in academic year 2015/2016 whose total is 150 students, and 90 students are taken clusterly as samples. In collecting the data, multiple choice tests were used as intruments. In analyzing the data results of the study, this reasearch used Pearson Product Moment Correlation (SPSS 20).

\section{FINDINGS AND DISCUSSION}

The main purpose of the research were to explore the influence of students' grammar and vocabulary mastery on their reading comprehension at Language Development Center of UIN SUSKA Riau.

After conducting try out of instrument tests, the scores of students' grammar mastery were taken from multiple choice which consisted of 20 questions consisting of four indicators for examples, grammatical tense, passive voice, adverbial connectors, and adjective clauses. The participants chose the answer by crossing (A, B, C or D), based on the true answer. Then, the scores of students' vocabulary mastery were taken from multiple choices which consisted of 20 questions consisting of four indicators for examples, nouns, verbs, adjectives, and adverbs. The participants chose the answer by crossing (A, B, C or D), based on the true answer given to the students. Lastly, the scores of students' reading comprehension were taken from multiple choices which consisted of 20 questions consisting of five indicators for examples, main idea, detail information, the meaning of vocabulary context, inferences, and references. The participants chose the answer by crossing (A, B, C or D), based on the true answer. After that, The classification of those students' 
test scores consisted of five categories such as, very good, good, sufficient, less, and fail (LDC Assessment, 2016). Here they are:

Table I.1. Percentage of Students' Grammar Mastery Score

\begin{tabular}{|l|l|l|l|}
\hline $\begin{array}{l}\text { N } \\
\mathbf{0}\end{array}$ & Category & $\begin{array}{l}\text { Frequen } \\
\text { cy }\end{array}$ & $\begin{array}{l}\text { Perce } \\
\text { ntage }\end{array}$ \\
\hline $\mathbf{1}$ & Very good & 11 & $12,2 \%$ \\
\hline $\mathbf{2}$ & Good & 39 & $43,3 \%$ \\
\hline $\mathbf{3}$ & Sufficient & 40 & $44,5 \%$ \\
\hline $\mathbf{4}$ & Less & - & - \\
\hline $\mathbf{5}$ & Fail & - & - \\
\hline & Total & $\mathbf{9 0}$ & $\mathbf{1 0 0 \%}$ \\
\hline
\end{tabular}

The table I.1 described that the students'grammar mastery were divided into five levels. There were very good (80-100), good (66-77), sufficient (56-61), less (40-55), fail (30-39). Based on the table IV.4, the highest frequency was in the sufficient level ( 40 students $=44.5 \%$ ), then it was followed by the good level (40 students $=43.3 \%)$, and the last wass in the very good level (11 students $=12.2 \%$ ). Based on this data, students' grammar mastery of the second level of Language Development Center of UIN SUSKA Riau was categorized into sufficient level.

Table I.2. Percentage of Students' Vocabulary Mastery Score

\begin{tabular}{|l|l|l|l|}
\hline $\mathbf{N}$ & Category & $\begin{array}{l}\text { Freque } \\
\text { ncy }\end{array}$ & $\begin{array}{l}\text { Percent } \\
\text { age }\end{array}$ \\
\hline $\mathbf{1}$ & Very good & 33 & $36,6 \%$ \\
\hline $\mathbf{2}$ & Good & 45 & $50 \%$ \\
\hline $\mathbf{3}$ & Sufficient & 12 & $36,6 \%$ \\
\hline $\mathbf{4}$ & Less & - & - \\
\hline
\end{tabular}

J-SHMIC, Vol 4, No 1, February 2017

\begin{tabular}{|l|l|l|l|}
\hline 5 & Fail & - & - \\
\hline & Total & $\mathbf{9 0}$ & $100 \%$ \\
\hline
\end{tabular}

The table I.2 described that students'vocabulary mastery were divided into five levels. There were very good (80-100), good (66-77), sufficient (56-61), less (40-55), fail (30-39). Based on the table IV.8, the highest frequency was in the good level (45 students $=50 \%)$, then it was followed by very good level (33 students $=36.6 \%$ ), and the last was in the sufficient level (12 students $=13.4 \%$ ). Based on this data, students' vocabulary mastery of the second level of Language Development Center of UIN SUSKA Riau was categorized into good level.

Table I.3. Percentage of Students' Reading Comprehension Score

\begin{tabular}{|l|l|l|l|}
\hline $\begin{array}{l}\mathbf{N} \\
\mathbf{0}\end{array}$ & Category & $\begin{array}{l}\text { Frequen } \\
\text { cy }\end{array}$ & $\begin{array}{l}\text { Percent } \\
\text { age }\end{array}$ \\
\hline $\mathbf{1}$ & Very good & 27 & $30 \%$ \\
\hline $\mathbf{2}$ & Good & 45 & $50 \%$ \\
\hline $\mathbf{3}$ & Sufficient & 18 & $\mathbf{2 0 \%}$ \\
\hline $\mathbf{4}$ & Less & - & - \\
\hline $\mathbf{5}$ & Fail & - & - \\
\hline & Total & $\mathbf{9 0}$ & $\mathbf{1 0 0 \%}$ \\
\hline
\end{tabular}

The table I.3 explained that students' reading comprehension were divided into five levels. There were very good (80-100), good (6677), sufficient (56-61), less (40-55), fail (30-39). Based on the table IV.12, the highest frequency was in the good level (45 students $=50 \%$ ), then it was followed by very good level (27 students $=30 \%$ ), and the last was in

The Influence of Grammar and Vocabulary Mastery on Students' Reading Comprehension at Language Development Center of UIN Suska Riau 
the sufficient level (18 students $=20 \%$ ). Based on this data, students' reading comprehension of the second level of Language Development Center of UIN SUSKA Riau was categorized into good level.

\section{Data analysis}

The data was analyzed and identified whether there was a positive significant influence between students' grammar mastery and vocabulary mastery on their reading comprehension which describe in the hypotheses. There are three hypotheses in this study as below:

The finding that there were 90 respondents for both variables grammar mastery and reading comprehension. The significant (2tailed) was 0.000 . The pearson correlation was 0.811 . In conclusion, hypothesis alternative (Ha1) was accepted. So, There was an influence of grammar mastery on students' reading comprehension of the second level at Language Development Center of UIN SUSKA Riau.

From the result, it is revealed that the students who have good mastery in grammar are able comprehend reading, because the rules of grammar help to determine the mechanics of reading, which what makes the connection between grammar and reading is important. According to Brown (2001: 362) states that grammar is the system of rules governing the conventional arrangement and relationship of words in a sentence. Considering that a correct grammar is important because grammatical mistakes can lead to misunderstanding what one is saying or writing. In addition, Jeffery
(1990 : 120) states that grammar is needed in order to gain control of written language for thought has to be organized in order to make meaning clear to readers.

The finding that there are 90 respondents for both variables grammar mastery and reading comprehension. Thes significant (2tailed) is 0.000 . The pearson correlation is 0.735 . In conclusion, hypothesis alternative (Ha2) is accepted. So, There is an influence of vocabulary mastery on students' reading comprehension of the second level of Language Development Center of UIN SUSKA Riau.

From the result, it can be obviously seen that students' vocabulary mastery takes a big part in acquiring reading comprehension. Moreover, Gleason and Ratner (1998: 1425) argues that development of vocabulary knowledge represents a continuum in which individual words move from unfamiliar to acquainted, and to established categories. This vocabulary development both pushes and is pushed forward by reading acquisition. The interconnectedness of reading and vocabulary development is shown by the influence of each to the other where advances in each influences the other.

The third hypothesis can be proved by statistical analysis using correlation. It is explained below:It is concluded that hypothesis alternative (Ha3) is accepted. So, There is an influence of grammar and vocabulary mastery on students' reading comprehension of the second level of Language Development Center of UIN SUSKA Riau Pekanbaru.

The Influence of Grammar and Vocabulary Mastery on Students' Reading Comprehension at Language Development Center of UIN Suska Riau 
From the result, grammar, vocabulary, and reading have correlation each other. Therefore, the students must know the vocabulary first because it is a base of language. It is impossible for the students to read a foreign language without having enough knowledge of vocabulary. Besides, grammar has important role in learning English, so it also has a big influence to reading comprehension. In addition, Koda (2007) that students who want to comprehend a text message, they have to know about how the text is form or they will not able to have complete understanding about the text is mean. So, when their score of grammar and vocabulary are high, their score in reading comprehension is also high.

\section{Discussion}

Before analyzing whether there was any significant influence between variables, the descriptive data of all variables were already analyzed. For instance, focusing on students'grammar mastery was categorized into sufficient level (40 students $=44.5 \%)$. Then, students'vocabulary mastery was categorized into good level (33 students $=36.6 \%$ ). Lastly, students'reading comprehension was categorized into good level (45 students $=50 \%$ ).

The result of research findings, the first finding of the research indicated that there was a positive influence between grammar mastery on students' reading comprehension which was proved by two ways in interpreting the result of correlation where the value $r_{x y}=0.811$ was between $0.800-1.00$ meant very high influence and by comparing the value of $r_{x y}=0.811$ with $r_{\text {table }}$ was $0.205<0.811>0.267$ that meant the $r_{x y}$ was a higher influence than $r_{\text {table. The }}$ second finding, there was a positive influence between vocabulary mastery on students' reading comprehension which was showed by two ways in interpreting the result of correlation where the value $r_{x y}=0.735$ was between $0.600-0.800$, that meant high influence and by comparing the value of $r_{x y}$ with $r_{\text {table }}$ was $0.205<0.735>0.267$ that meant $r_{x y}$ was higher than $r_{\text {table. The last }}$ finding, there was a positive influence between grammar and vocabulary mastery on students' reading comprehension of the second level students of Animal and Agricultural Husbandry at Language Development Center of UIN SUSKA Riau which was proved by two ways in interpreting the result of correlation where the value $R_{y \cdot x_{1} x_{2}}=$ 0.82969 was between $0.800-1.00$, that meant very high influence and by comparing the value of $R_{y \cdot x_{1} x_{2}}=$ 0.82969 with $r_{\text {table }}$ was " $0.205<0.82969>0.267$ " that meant $R_{y . x_{1} x_{2}}$ was higher than $\mathrm{r}_{\text {table. }}$

So, the statements are revealed vocabulary and grammar which are the important in learning language especially in reading comprehension. Vocabulary was the first stage to learn and to know the text itself. Because, if the students have a few vocabularies, they will find difficulties to comprehend the text. Therefore, the student must master grammar formations if they want to improve their comprehension in reading.

The Influence of Grammar and Vocabulary Mastery on Students' Reading Comprehension at Language Development Center of UIN Suska Riau 


\section{CONCLUSIONS}

The main goal of the research was to find out the influence of grammar and vocabulary mastery on the students' reading comprehension of the second level of Animal Husbandry major at Language Development Center of UIN SUSKA Riau Pekanbaru. Specifically, the study was done to fulfil the objectives such as, to find out the influence of grammar mastery on the students' reading comprehension, then to find out the influence of vocabulary mastery on the students' reading comprehension, and lastly to find out the influence of grammar and vocabulary mastery on the students' reading comprehension of the second level of Language Development Center of UIN SUSKA Riau. there was a positive influence between grammar and vocabulary mastery on students' reading comprehension of the second level students of Animal and Agricultural Husbandry at Language Development Center of UIN SUSKA Riau which was proved by two ways in interpreting the result of correlation where the value $R_{y \cdot x_{1} x_{2}}=0.82969$ was between $0.800-1.00$, that meant very high influence and by comparing the value of $R_{y \cdot x_{1} x_{2}}=0.82969$ with $\mathrm{r}_{\text {table }}$ was " $0.205<0.82969>0.267$ " that meant $R_{y \cdot x_{1} x_{2}}$ was higher than $\mathrm{r}_{\text {table. }}$.

After drawing the inferences, there were several suggestions that hopefully could give the constructive ideas for the readers, especially for English lecturers, students, and future researchers. The English lecturer should give more explanation and attention to the students about the aspects of reading comprehension especially in the aspect of determining main idea. The lecturers might give more practice of reading by giving exercises on identfying main idea, the detail information, reference, inference, and understanding vocabularies.

Then the students should be aware to increase their own mastery in grammar and vocabulary in order to they are going to easily comprehend the text reading. The students should change the way of learning of grammar lesson and reading lesson. For grammar lesson the student need to follows the role of grammar steps by steps. On the other hand while the students learn reading, they had to learn about many things, such as linguistic, word knowledge, organization of text structure, micro reading skill, and also reading strategies. Lastly, the future researchers might study deeper and more about the process of learning and teaching, the techniques and procedures of giving of final score, and the content of the test itself. Besides that, the use of different population and sample were recommended.

\section{REFERENCES}

Aebersold, J.A. \& Field, M. L. (1997). Vocabulary issues in teaching reading. From Reader to Reading Teacher: Issues and Strategies for Second Language Classrooms. Cambridge: Cambridge University Press.

Alfiah, S. 2011. The correlation between students' understanding of sentence pattern, vocabulary mastery and their reading

The Influence of Grammar and Vocabulary Mastery on Students' Reading Comprehension at Language Development Center of UIN Suska Riau 
comprehension achievement at the second year of SMAN 1 Pagelaran. Bandar Lampung: Lampung University.

Brown, H. D. 2001. Teaching by principles, An interactive approach to language pedagogy. San Fransisco: Longman.

Creswell, John W. 2009. Research Design Qualitative, Quantitative, and Mixed Methods Approaches. London: Sage Publication, Inc.

Fries, C. 1990. Linguistics and Reading. New York: Holt. Rinehort \& Wintson.

Gleason, J and Ratner. B. 1998. Psycholinguistics. California: Thomson Wadsworth

Graham, Steve. 2007. Teaching Reading Comprehension to Students with Leaning Difficulties. New York: The Guilford Press.

Jeffery, C.D. 1990. The Case for Grammar: Openinmg it Wider. South African Journal of Higher Education, Special Edition.

Koda, keiko. 2007. Reading and Language Learning. Oxford Blackwell.UK.

King, Carol and Nancy Stanley. 2008. Building Skills for TOEFL 2nd $E d$. Longman. London.

Krashen, S. 2004. The power of reading. Englewood, Colorado: Libraries. Unlimited.
Lang Murcia, M. C. 2001. Teaching english as a second or foreign language. Boston: Heinle Thompson Learning.

Linse, Caroline T. 2005. Practical English Language Teaching. New York: Grow-Hill Companies.

Murcia, C. M. 2001. Teaching English as Second of Foreign Language. California: Amazone warehouse.

Nunan, David. (2003). Pactical English Language Teaching. New York: The McGraw-Hill Companies.

Nunan, David. (2003). Dynamic Text Comprehension An Integrative View of Reading. New York: Phoenix ELT.

Nunan, David. 2003. Pactical English Language Teaching. New York: The McGraw-Hill Companies.

Thornbury, S. 2002. How to Teach Vocabulary, Harlow: Pearson.

Wahyuni, E. 2011. Correlation between reading habit and reading comprehension achievement in intensive reading at second year student of SMA Surya Dharma 2 Bandar Lampung. Bandar Lampung: Lampung University. http://journals.tclibrary.org/index.php/tesol/article /viewFile/483/298 (15 December 2014). 